\title{
Spring burning Japanese brome in a western wheatgrass community
}

\author{
STEVEN G. WHISENANT AND DANIEL W. URESK
}

\begin{abstract}
Plots dominated by Japanese brome (Bromus japonicus) and western wheatgrass (A gropyron smithii) were burned in Badlands National Park, South Dakota, in April 1983 and/or 1984. Standing crop of all species and tiller densities of the 2 dominate species were determined for 4 years. Burning favored western wheatgrass and reduced Japanese brome tiller density and standing crop for at least 1 growing season. In years where no burning occurred, Japanese brome standing crop and tiller density were dependent on the presence of litter on the soil surface. Burning in April killed Japanese brome seedlings for 1 growing season and reduced subsequent generations by reducing surface litter accumulations, with the effect being greatest when autumn precipitation was below average. April burning reduced the standing crop of green needlegrass (Stipa viridula) for at least 3 growing seasons after burning but increased standing crop of buffalograss (Buchloe dactyloides) and sand dropseed (Sporobolus cryptandrus) for 3 to 4 years after burning. Threadleaf sedge (Carex filifolia) standing crop was not significantly affected by burning.
\end{abstract}

Key Words: Bromus japonicus, Agropyron smithi, Sporobolus cryptandrus, Buchloe dactyloides, Carex filfolia, Stipa viridula

Managed natural areas and parks in the northern Great Plains have often excluded fire and livestock. The resulting increased litter accumulations may have been partially responsible for the increased abundance of Japanese brome (Bromus japonicus Thunb.). Japanese brome is an exotic, annual grass which has become a common component of many mixed prairie communities. Kirsch and Kruse ( 1972) hypothesized that reduced fire frequencies-and the resulting higher litter accumulations-following the settlement of the northern Great Plains aided the establishment and spread of Japanese brome.

Year-to-year differences in populations of annual grasses have usually been attributed to different climatic or microenvironmental conditions. For example, plant litter on the soil surface was found to enhance establishment of downy brome (Bromus tectorum L.) in Nevada by creating a seedbed environment more conducive to seed germination and seedling establishment (Evans and Young 1970).

Prescribed fire has been suggested as a possible method of reducing Japanese brome abundance. Gartner et al. (1978) stated that burning in the fall, winter, or spring reduced Japanese brome densities for 2 growing seasons in South Dakota. Another study conducted in South Dakota during 2 years with above-average rainfall concluded that fire killed Japanese brome seedling but had little impact on subsequent generations of Japanese brome (Whisenant and Bulsiewicz 1986). Whisenant et al. (1984) stated that Japanese brome seedlings in Texas were killed by fire but popula-

Authors are associate professor, Department of Range Science, Texas A\&M University, College Station 77843-2126; and project leader Rocky Mountain Forest and Range Experiment Station, South Dakota School of Mines, Rapid City 57701. S.G. Whisenant was associate professor, Department of Botany and Range Science, Brigham Young University, Provo, Utah when the research was conducted.

Research was funded in part by the University of Wyoming-National Park Service Research Center (NPS CX-1200-4-A039), Brigham Young University, and the U.S. Forest Service, Rocky Mountain Forest and Range Experiment Station.

We thank Lloyd Kortge and Mike Glass of Badlands National Park for their assistance during this study.

Manuscript accepted 27 July 1989. tions returned to unburned levels during the second growing season. A Montana study indicated spring burning resulted in good Japanese brome control for 1 growing season after burning but did not evaluate the treatments in subsequent years (White and Currie 1983). These studies indicate a potential for Japanese brome control during the first post-burn growing season, but do not provide a clear understanding of what happens in subsequent years. A longer-term study which examines the causes of Japanese brome population changes would yield a clearer indication of the effects of burning on Japanese brome.

Understanding the dynamics of Japanese brome populations and using that information to develop burning strategies requires an understanding of the relationships between fire, Japanese brome, precipitation, and plant litter. The primary objective of this study was to determine the relationship between Japanese brome, precipitation, and litter frequency by examining post-burn tiller density and standing crop responses. The secondary objective was to follow standing crop changes. Following these attributes for 3 to 4 growing seasons after fires conducted in different years was an important component of this study. This enabled us to study Japanese brome response to burning under a variety of environmental conditions.

\section{Study Areas and Methods}

\section{Study Area}

The study area was in Badlands National Park in west-central South Dakota. Mean annual precipitation for the study area is about $38 \mathrm{~cm}$. Western wheatgrass ( Agropyron smithii Rydb.) and Japanese brome were codominants on the study plots. Green needlegrass [Stipa viridula (Trin.)], sand dropseed [Sporobolus cryptandrus (Torr.) A. Gray], threadleaf sedge [Carex filifolia (Nutt.)], and buffalograss [Buchloe dactyloides (Nutt.) Engelm.] were less abundant. The soil was a Larvie silty clay (fine, montmorillonitic, mesic vertic Camborthid).

The area had not been cultivated or grazed by domestic livestock for at least 25 years. There were white-tailed deer (Odocoileus virginianus), pronghorn (Antilocapra americana), bison (Bison bison), and a few Rocky Mountain bighorn sheep (Ovis canadensis canadensis) within the park boundary. Grazing was spread over $415 \mathrm{~km}^{2}$ and the effects were not apparent on the study site. In this relatively undisturbed area, Japanese brome maintained tiller densities averaging $1,500 \mathrm{~m}^{-2}$ in a good stand of native, perennial grass ( 273 western wheatgrass tillers $\mathrm{m}^{-2}$ ).

\section{Experimental Design and Data Collection}

Twelve 5- by 5-m plots were established in a randomized complete block design with 3 replications of 4 treatments. Treatments were: (1) unburned, (2) burned 20 April 1983, (3) burned 16 April 1984, (4) burned 20 April 1983 and 16 April 1984.

Fine-fuel weight and fuel-water contents were determined before each burn by clipping $5,0.10 \mathrm{~m}^{-2}$ quadrats, drying at $60^{\circ} \mathrm{C}$ for 48 $\mathrm{hr}$, and weighing. Air temperature, relative humidity, and instantaneous wind speed were measured with a mercury thermometer, sling psychrometer, and a hand-held wind meter immediately before, during and after each fire. 


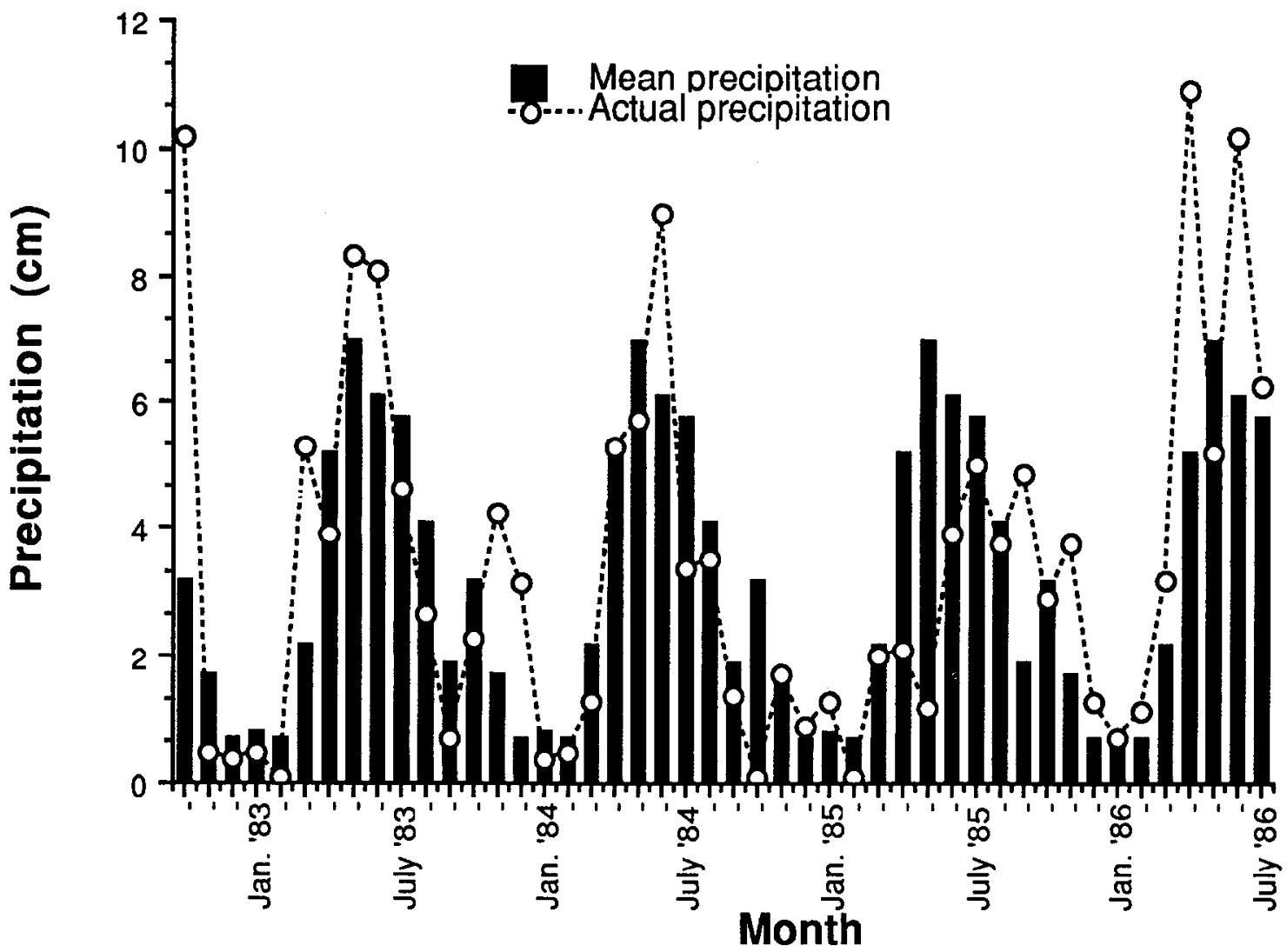

Fig. 1. Actual and long-term mean precipitation for the study site at Badlands National Park, South Dakota.

Litter frequency was determined each year with 10 placements of a 10-point frame in each plot. Therefore, plot frequency was based on 100 points per plot. Japanese brome tiller density in July was used as the dependent variable and litter frequency and fall precipitation (October and November) were used as independent variables in regression analysis.

Western wheatgrass and Japanese brome tiller densities and standing crops were determined in July 1983, 1984, 1985, and 1986 using 5 placements of a $0.10-\mathrm{m}^{2}$ quadrat on each plot. Tiller density was measured on permanently marked locations, so that data in different years were collected on the same spots. When several Japanese brome seeds within an intact, buried spikelet germinated, it was difficult to discern individual plants without destructive sampling. However, most Japanese brome tillers were individual plants, thus tiller density was considered a good approximation of plant density. Individual western wheatgrass plants were also difficult to determine, so tiller density was used. Standing crops in July $1983,1984,1985$, and 1986 were used as an estimate of annual above-ground production. Significant treatment differences in each of the response variables (density and standing crop) were determined with analysis of variance and Tukey's HSD procedure at the $5 \%$ level.

\section{Results and Discussion}

\section{Environmental Conditions}

During the 1983 and 1984 fires, Japanese brome seedlings were approximately 3- to 5-cm in height, but few western wheatgrass tillers had emerged. Fires on 20 April 1983 were conducted at $22^{\circ} \mathrm{C}$ and $40 \%$ relative humidity, with $211 \mathrm{~g} \mathrm{~m}^{-2}$ (18\% fuel water) and winds of 6 to $9 \mathrm{~km} \mathrm{hr}^{-1}$. Fires on 16 April 1984 were conducted at $14^{\circ} \mathrm{C}$ and $43 \%$ relative humidity, with $276 \mathrm{~g} \mathrm{~m}^{-2}$ (13\% fuel water) and winds of 5 to $13 \mathrm{~km} \mathrm{hr}^{-1}$. On 16 April 1984 those plots also burned in 1983 contained $139 \mathrm{~g} \mathrm{~m}^{-2}$ (20\% fuel water). Growing conditions were less favorable for plant growth in 1985 because of reduced precipitation (Fig. 1).

\section{Japanese Brome}

Spring burning significantly reduced both the number and standing crop of Japanese brome plants for the first growing season (Tables 1 and 2). This reduction occurred following the 1983 and 1984 burns and on plots burned in both years. In 1984, plots previously burned in 1983 contained too little fuel for a satisfactory burn. As a result, Japanese brome density in 1984 was greater on plots burned 2 consecutive years than on plots only burned in 1984 (Table 1).

Table 1. Tiller densities $\left(\mathrm{m}^{-2}\right)$ of Japanese brome and western wheatgrass in July following burning on 20 April 1983 and/or 16 April 1984 in Badlands National Park, South Dakota1.

\begin{tabular}{lcrrrr}
\hline \hline & Year & \multicolumn{4}{c}{ Evaluation year } \\
\cline { 3 - 6 } Species & bumed & 1983 & 1984 & 1985 & 1986 \\
\hline Japanese brome & None & $2328 \mathrm{a}$ & $2617 \mathrm{a}$ & $306 \mathrm{a}$ & $467 \mathrm{a}$ \\
& 1983 & $690 \mathrm{~b}$ & $2456 \mathrm{a}$ & $217 \mathrm{~b}$ & $342 \mathrm{a}$ \\
& 1984 & $2250 \mathrm{a}$ & $23 \mathrm{c}$ & $14 \mathrm{c}$ & $112 \mathrm{~b}$ \\
& $1983 \& 1984$ & $719 \mathrm{~b}$ & $580 \mathrm{~b}$ & $81 \mathrm{c}$ & $196 \mathrm{~b}$ \\
Western wheatgrass & None & $295 \mathrm{~b}$ & $375 \mathrm{~b}$ & $222 \mathrm{ab}$ & $206 \mathrm{~b}$ \\
& 1983 & $453 \mathrm{a}$ & $304 \mathrm{~b}$ & $172 \mathrm{~b}$ & $237 \mathrm{~b}$ \\
& 1984 & $300 \mathrm{~b}$ & $507 \mathrm{a}$ & $299 \mathrm{a}$ & $424 \mathrm{a}$ \\
& $1983 \& 1984$ & $432 \mathrm{a}$ & $333 \mathrm{~b}$ & $153 \mathrm{~b}$ & $319 \mathrm{ab}$ \\
\hline
\end{tabular}

${ }^{1}$ Means, within a species and evaluation date, followed by the same letter are not significantly different $(P \leq 0.05)$ according to Tukey's HSD procedure. 
Table 2. Above-ground standing crops $\left(\mathrm{g} \mathrm{m}^{-2}\right)$ of 6 species in July following hurning on 20 April 1983 and/or 16 April 1984 in Badlands National Park, South Dakota'.

\begin{tabular}{|c|c|c|c|c|c|}
\hline \multirow[b]{2}{*}{ Species } & \multirow{2}{*}{$\begin{array}{l}\text { Year } \\
\text { burned }\end{array}$} & \multicolumn{4}{|c|}{ Evaluation year } \\
\hline & & 1983 & 1984 & 1985 & 1986 \\
\hline Japanese brome & $\begin{array}{c}\text { None } \\
1983 \\
1984 \\
1983 \& 1984\end{array}$ & $\begin{array}{l}75 a \\
35 b \\
81 a \\
43 b\end{array}$ & $\begin{array}{r}75 a \\
101 a \\
4 b \\
14 b\end{array}$ & $\begin{array}{r}21 \mathrm{a} \\
19 \mathrm{a} \\
1 \mathrm{a} \\
2 \mathrm{a}\end{array}$ & $\begin{array}{r}150 \mathrm{a} \\
123 \mathrm{a} \\
18 \mathrm{~b} \\
85 \mathrm{a}\end{array}$ \\
\hline Western wheatgrass & $\begin{array}{c}\text { None } \\
1983 \\
1984 \\
1983 \& 1984\end{array}$ & $\begin{array}{r}88 a \\
105 a \\
82 a \\
93 a\end{array}$ & $\begin{array}{r}106 \mathrm{a} \\
42 \mathrm{~b} \\
112 \mathrm{a} \\
92 \mathrm{a}\end{array}$ & $\begin{array}{l}51 \mathrm{a} \\
37 \mathrm{a} \\
66 \mathrm{a} \\
36 \mathrm{a}\end{array}$ & $\begin{array}{r}58 b \\
86 b \\
182 \mathrm{a} \\
80 \mathrm{~b}\end{array}$ \\
\hline Buffalo grass & $\begin{array}{c}\text { None } \\
1983 \\
1984 \\
1983 \& 1984\end{array}$ & $\begin{array}{l}4 b \\
8 a \\
5 b \\
7 a\end{array}$ & $\begin{array}{r}6 \mathrm{~b} \\
10 \mathrm{a} \\
9 \mathrm{a} \\
9 \mathrm{a}\end{array}$ & $\begin{array}{l}2 \mathrm{~b} \\
5 \mathrm{a} \\
5 \mathrm{a} \\
5 \mathrm{a}\end{array}$ & $\begin{array}{l}7 \mathrm{a} \\
6 \mathrm{a} \\
8 \mathrm{a} \\
8 \mathrm{a}\end{array}$ \\
\hline Sand dropseed & $\begin{array}{c}\text { None } \\
1983 \\
1984 \\
1983 \& 1984\end{array}$ & $\begin{array}{l}2 \mathrm{~b} \\
5 \mathrm{a} \\
3 \mathrm{~b} \\
5 \mathrm{a}\end{array}$ & $\begin{array}{l}2 c \\
5 \mathrm{ab} \\
6 \mathrm{a} \\
4 \mathrm{~b}\end{array}$ & $\begin{array}{l}1 \mathrm{c} \\
4 \mathrm{a} \\
5 \mathrm{a} \\
3 \mathrm{~b}\end{array}$ & $\begin{array}{l}3 \mathrm{~b} \\
5 \mathrm{a} \\
7 \mathrm{a} \\
5 \mathrm{~b}\end{array}$ \\
\hline Green needlegrass & $\begin{array}{c}\text { None } \\
1983 \\
1984 \\
1983 \& 1984\end{array}$ & $\begin{array}{l}3 a \\
1 b \\
4 a \\
0 c\end{array}$ & $\begin{array}{l}4 a \\
1 b \\
0 c \\
0 c\end{array}$ & $\begin{array}{l}3 \mathrm{a} \\
0 \mathrm{c} \\
1 \mathrm{~b} \\
0 \mathrm{c}\end{array}$ & $\begin{array}{l}6 \mathrm{a} \\
2 \mathrm{~b} \\
1 \mathrm{~b} \\
\mathrm{lb}\end{array}$ \\
\hline
\end{tabular}

'Means, within a species and evaluation date, followed by the same letter are not significantly different ( $P \leq 0.05$ ) according to Tukey's HSD procedure.

In a dry year (i.e., 1985), Japanese brome densities and standing crops were lower on all plots, with the reductions being greatest on plots with less frequent surface litter (Tables 1 and 2). When Japanese brome densities in July were plotted as a function of litter frequency on those plots not burned in the same year, this relationship was readily apparent (Fig. 2). Plots burned in the same year were excluded from this analysis because the fire killed the Japanese brome seedings and subsequent density was a function of fire rather than litter. Linear regression using July density as the dependent variable and litter frequency as the independent variable indicated a significant $(p<0.05)$ relationship. The resulting equation was: $Y=264.9+B_{1} *(27.1)\left(r^{2}=0.62\right)$ where $Y$ is Japanese brome tiller density in July and $B_{1}$ is litter frequency. Litter frequency was less important when the autumn precipitation was above average. The greater variability at low litter frequencies (Fig. 2) occurred when the previous autumn precipitation was high and tiller densities were high even when litter frequency was low. Adding October and November precipitation $(\mathrm{cm})$ as an independent variable increased the $r^{2}$ from 0.62 to 0.67 , with the resulting equation: $Y=-156.9+B_{1}^{*}(21.7)+B_{2}^{*}(10.9)$ where $B_{2}$ is October and November precipitation $(\mathrm{cm})$.

The major influence of burning on subsequent generations of Japanese brome was through modification of the microenvironment, principally surface litter frequency. Without livestock, litter accumulations in the northern mixed prairie stabilize 5 to 6 years after burning (Dix 1960, Abougendia and Whitman 1979). Burning intervals of less than 5 years should reduce litter and Japanese brome densities. Japanese brome germination, like downy brome (Evans and Young 1984), required some litter on the soil surface, particularly when autumn precipitation was below average. This creates a paradox for natural resource managers. Management practices designed to improve these grasslands (i.e., reduced grazing which increases litter) create a more desirable microenvironment for this introduced species. This can also be observed indirectly, by comparing the abundance of Japanese brome in the grasslands of Badlands National Park with that of surrounding

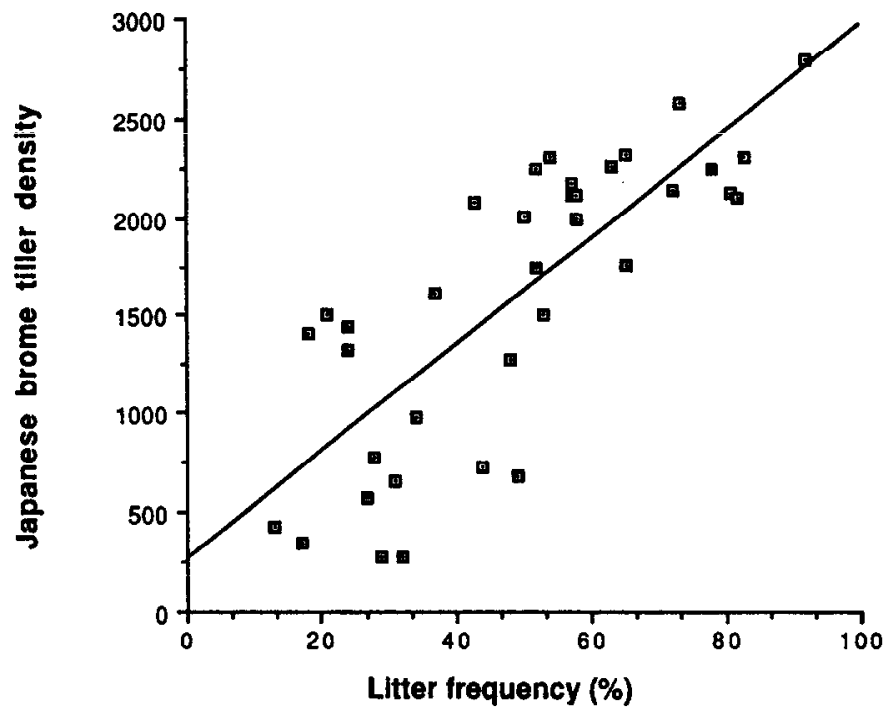

Fig. 2. Relationship of Japanese brome tiller densities $\left(\mathrm{m}^{-2}\right)$ and surface frequency (\%) on plots at Badlands National Park (Juby density $=264.9+$ litter frequency ${ }^{*}(27.1)\left(r^{2}=0.62\right)$. Data from plots burned during the same year were excluded from this analysis.

grasslands grazed by domestic livestock. Japanese brome abundance of the surrounding rangelands appears to be much lower than within Badlands National Park (Uresk 1984).

Seed immigration into the plots was not measured, but did not appear to be a coniroling factor. A previous study in this area indicated that Japanese brome seed banks are large $(11,000$ to $12,000 \mathrm{~m}^{-2}$ ) (Whisenant and Bulsiewicz 1986) and probably last for several years. Although seeds were abundant, Japanese brome populations were reduced for at least 2 to 3 years after burning (Table 1). The longer-term response to burning was a function of precipitation and litter accumulations, rather than seed availability.

These data strongly indicate that spring burning will not greatly reduce more than 1 generation of Japanese brome, unless burning is followed by dry weather. Japanese brome germination is largely dependent on litter accumulations and Japanese brome will increase as litter accumulates on the soil surface. Livestock grazing and/or fire decrease litter accumulations and will reduce Japanese brome. It is highly unlikely that a reasonable grazing and prescribed burning program would remove Japanese brome from these communities, but it could significantly reduce the relative herbage contribution of Japanese brome.

\section{Western Wheatgrass}

Burning increased western wheatgrass tiller densities and standing crops during the first growing season after burning (Tables 1 and 2). However, during the second growing season both tiller densities and standing crops were similar to untreated plots. Clarke et al. (1943) reported spring burning on a western wheatgrassthickspike wheatgrass [Agropyron dasystachyum (Hook.) Scribn.] community reduced standing crops $50 \%$ the first year, $15 \%$ the second year with full recovery in the third year. In western South Dakota spring burning usually increases western wheatgrass production (Schripsema 1977, Gartner et al. 1978). Spring burning in the semiarid northern, mixed prairie of eastern Montana increased standing crops of western wheatgrass for the first post-burn growing season (White and Currie 1983). They suggested that additional research was necessary to evaluate the persistence of burning effects.

The persistence of burning effects on western wheatgrass was greatly influenced by Japanese brome abundance. Western wheatgrass densities and standing crops were increased during the first 
growing season after burning. When the second postburn growing season was favorable for Japanese brome growth (i.e., 1984), western wheatgrass standing crops and tiller densities were reduced. When the second postburn growing season was unfavorable for Japanese brome (i.e., 1985), western wheatgrass standing crops and tiller densities were increased relative to the unburned plots.

\section{Green Needlegrass and Threadleaf Sedge}

Burning in April significantly reduced the standing crop of green needlegrass for at least 3 growing seasons after burning (Table 2). All 3 burning treatments reduced standing crops to about one third that on unburned plots. Coupland (1973) studied the effects of an August wildfire on green needlegrass in southwestern Saskatchewan and found herbage yields were increased $45 \%$ one year after the fire. Dix (1960) found that a late May wildfire increased green needlegrass frequency in western North Dakota. Schripsema (1977) found spring burning decreased green needlegrass in western South Dakota. Wright and Bailey (1982) considered current information on the effects of fire on green needlegrass to be inadequate. The results of this study were similar to those from a more recent study by Engle and Bultsma (1984), which found that burning in May or June-during a drought - was detrimental to green needlegrass. Based on the results of this and other studies, green needlegrass should be considered intolerant of spring burning.

Threadleaf sedge standing crops were not significantly affected by any of the 3 burning treatments in this study (data not shown). This is consistent with data from eastern Montana (White and Currie 1983) and western South Dakota (Schripsema 1977) where spring burning had little effect on threadleaf sedge, except during a dry year.

\section{Buffalograss and Sand Dropseed}

Buffalograss standing crops were increased for 2 to 3 years after burning (Table 2). In western South Dakota spring burning increased buffalograss production (Schripsema 1977). April burning of loess hills mixed prairie in southern Nebraska had no significant effect on buffalograss standing crops (Schacht and Stubbendieck 1985). Spring burning increased sand dropseed standing crops for 3 to 4 growing seasons (Table 2). Burning 2 consecutive years also increased sand dropseed standing crops. These data are consistent with the data of Schacht and Stubbendieck (1985) who found sand dropseed increased following spring burning. A study of the long-term effects of fire or major grass species of west Texas indicated that buffalograss and sand dropseed were neither harmed nor benefitted by fire (Wright 1974).

Spring burning increased the productivity of $\mathrm{C}_{4}$ species (i.e., buffalograss and sand dropseed), although $\mathrm{C}_{3}$ species continued to dominate the community. The $\mathrm{C}_{4}$ species were a relatively minor component of the total productivity. Composition shifts toward $\mathrm{C}_{4}$ species have also been reported following spring burning in the mesic mixed prairie of north-central South Dakota by Steuter (1987) and Engle and Bultsma (1984).

\section{Design Considerations}

The plot size used in this study ( 5 by $5 \mathrm{~m}$ ) may not have allowed the fire to develop maximum potential intensity. However, there is considerable support for the use of small plots in research involving uniformly distributed grass species. This approach has been used by several investigators to reduce site, soil, and topographic variability (Old 1969, Hulbert 1969, Sharrow and Wright 1977, Whisenant et al. 1984, White and Currie 1983, Hulbert 1988). Other studies have found that temperature differences due to plot size were of little importance. Heyward (1938) found temperatures were no different in fires 3 by $3 \mathrm{~m}$ and those $16 \mathrm{ha}$ in size. Daubenmire (1968) concluded that for areas 3 by $3 \mathrm{~m}$ or larger, size was not important in experimental burning or grasslands. Stinson and Wright (1969) stated "where the chief fuel is grass, size of plot for measuring temperatures is of minor importance." In addition, most studies have attributed the effects of burning grasslands to litter removal and alterations in the microenvironment rather than to the direct effects of heat (Old 1969, Hulbert 1969, Sharrow and Wright 1977, Whisenant et al. 1984, Hulbert 1988). Where grasses are of primary concern and uniformly distributed, the potential problems resulting from the use of small plots are minor relative to the advantages of their use.

\section{Literature Cited}

Abouguendia, Z.M., and W.C. Whitman. 1979. Disappearance of dead plant material in a mixed grass prairie. Oecologia 42:23-29.

Clarke, S.E., E.W. Tisdale, and N.A. Skoglund. 1943. The effects of climate and grazing on shortgrass prairie vegetation. Canadian Dominion Dep. Agr. Tech. Bull. 46:53.

Connell, J.H., and R.O. Slatyer. 1977. Mechanisms of succession in natural communities and their role in community stability and organization. Amer. Natur. 111:1119-1144.

Coupland, R.T. 1973. Procedures: I. Dynamics of above-ground standing crop. Matodor Project. Canadian IBP Prog. Tech. Rep. 27. Saskatoon, Sask.

Daubenmire, R. 1968. Ecology of fire in grasslands. Adv. Ecol. Res. 5:209-266.

Dix, R.L. 1960. The effects of burning on the mulch structure and species composition of grasslands in western North Dakota. Ecol. 41:49-56.

Egler, F.E. 1954. Vegetation science concepts. I. Initial floristic composition-a factor in old-field vegetation development. Vegetatio 4:412-417.

Evans, R.A., and J.A. Young. 1970. Plant litter and establishment of alien annual weed species in rangeland communities. Weed Sci. 18:697-703.

Gartner, F.R., R.I. Butterfield, W.W. Thompson, and L.R. Roath. 1978. Prescribed burning of range ecosystems in South Dakota. Internat. Rangeland Congr. 1:687-690.

Heyward, F. 1938. Soil temperatures during forest fires in the longleaf pine region. J. For. 36:478-491.

Hulbert, L.C. 1969. Fire and litter effects in undisturbed bluestem prairie in Kansas. Ecology 50:874-877.

Hulbert, L.C. 1988. Causes of fire effects in tallgrass prairie. Ecology: 46:58.

Kirsch, C.L., and A.D. Kruse. 1970. Prairie fires and wildlife. Proc. Annu. Tall Timbers Fire Ecol. Conf. 12:289-303.

Old, S.M. 1969. Microclimate, fire and plant production in an Illinois prairie. Ecol. Monogr. 39:355-384.

Schacht, W., and J. Stubbendieck, 1985. Prescribed burning in the loess hills mixed prairie of southern Nebraska. J. Range Manage. 38:47-51.

Schripsema, J.R. 1977. Ecological changes on pine-grassland burned in spring, late spring, and winter. M.A. Thesis. Biology-Botany Dep. South Dakota State Univ., Brookings.

Sharrow, S.H., and H.A. Wright. 1977. Effects of fire, ash, and litter on soil nitrate, temperature, moisture and tobosagrass production in the Rolling Plains. J. Range Manage. 30:266-270.

Steuter, A.A. 1987. $C_{3} / C_{4}$ production shift on seasonal burns-northern mixed prairie. J. Range Manage. 40:27-31.

Stinson, K.J., and H.A. Wright. 1969. Temperatures of headfires in the southern mixed prairie of Texas. J. Range Manage. 169-174.

Uresk, D.W. 1984. Black-tailed prairie dog food habits and forage relationships in western South Dakota. J. Range Manage. 37:325-329.

Whisenant, S.G., and W.G. Bulsiewicz. 1986. Effects of prescribed burning on Japanese brome population dynamics. Internat. Grassl. Congr. 15:803-804.

Whisenant, S.G., D.N. Ueckert, and C.J. Scifres. 1984. Effects of fire on Texas wintergrass communities. J. Range Manage. 27:387-391.

White, R.S., and P.O. Currie. 1983. Prescribed burning in the northern Great Plains: yield and cover responses of 3 forage species in the mixed grass prairie. J. Range Manage. 36:179-183.

Wright, H.A. 1974. Effect of fire on southern mixed prairie grasses. J. Range Manage. 27:417-419.

Wright, H.A., and A.W. Bailey. 1982. Fire ecology. John Wiley and Son, NY.

Young, J.A., and R.A. Evans. 1978. Population dynamics after wildfires in sagebrush grasslands. J. Range Manage. 31:283-289. 